\title{
Antimicrobial Activity of Cinnamaldehyde on Streptococcus mutans Biofilms
}

\author{
Zhiyan He ${ }^{1,2}$, Zhengwei Huang ${ }^{2,3}$, Wei Jiang ${ }^{2,3 *}$ and Wei Zhou ${ }^{1,2 *}$ \\ ${ }^{1}$ Laboratory of Oral Microbiota and Systemic Diseases, Shanghai Key Laboratory of Stomatology and Shanghai Research \\ Institute of Stomatology, Shanghai Ninth People's Hospital, College of Stomatology, Shanghai Jiao Tong University School of \\ Medicine, Shanghai, China, ${ }^{2}$ National Clinical Research Center for Oral Diseases, Shanghai Key Laboratory of Stomatology \\ and Shanghai Research Institute of Stomatology, Shanghai, China, ${ }^{3}$ Department of Endodontics, Shanghai Ninth People's \\ Hospital, College of Stomatology, Shanghai Jiao Tong University School of Medicine, Shanghai, China
}

\section{OPEN ACCESS}

Edited by:

Fabian Cieplik,

University Medical Center

Regensburg, Germany

Reviewed by:

Naile Dame-Teixeira,

University of Brasilia, Brazil

Tim Maisch,

University of Regensburg, Germany

${ }^{*}$ Correspondence:

Wei Zhou

sweetzw@hotmail.com

Wei Jiang

jiangweishanghai@126.com

Specialty section

This article was submitted to

Antimicrobials, Resistance

and Chemotherapy,

a section of the journal

Frontiers in Microbiology

Received: 09 May 2019

Accepted: 12 September 2019

Published: 25 September 2019

Citation:

He Z, Huang Z, Jiang W and Zhou W (2019) Antimicrobial Activity of Cinnamaldehyde on Streptococcus

mutans Biofilms.

Front. Microbiol. 10:2241. doi: 10.3389/fmicb.2019.02241
Streptococcus mutans is considered the most relevant bacteria in the transition of non-pathogenic commensal oral microbiota to biofilms which contribute to the dental caries process. The present study aimed to evaluate the antimicrobial activity of a natural plant product, cinnamaldehyde against S. mutans biofilms. Minimum inhibitory concentrations (MIC), minimal bactericidal concentration (MBC), and growth curves were determined to assess its antimicrobial effect against planktonic S. mutans. The biofilm biomass and metabolism with different concentrations of cinnamaldehyde and different incubation time points were assessed using the crystal violet and MTT assays. The biofilms were visualized using confocal laser scanning microscopy (CLSM). Bacterial cell surface hydrophobicity, aggregation, acid production, and acid tolerance were evaluated after cinnamaldehyde treatment. The gene expression of virulence-related factors ( $g t f B, g t f C, g t f D, g b p B, c o m D E, v i c R, c i a H, I d h$ and relA) was investigated by real-time PCR. The MIC and MBC of cinnamaldehyde against planktonic S. mutans were 1000 and $2000 \mu \mathrm{g} / \mathrm{mL}$, respectively. The results showed that cinnamaldehyde can decrease biofilm biomass and metabolism at sub-MIC concentrations. CLSM images revealed that the biofilm-covered surface areas decreased with increasing concentrations of cinnamaldehyde. Cinnamaldehyde increased cell surface hydrophobicity, reduced S. mutans aggregation, inhibited acid production, and acid tolerance. Genes expressions in the biofilms were downregulated in the presence of cinnamaldehyde. Therefore, our data demonstrated that cinnamaldehyde at sub-MIC level suppressed the microbial activity on S. mutans biofilm by modulating hydrophobicity, aggregation, acid production, acid tolerance, and virulence gene expression.

Keywords: Streptococcus mutans, cinnamaldehyde, biofilm, antimicrobial activity, virulence, dental caries

\section{INTRODUCTION}

Dental caries is a disease of chronic progressive destruction that occurs as a result of dysbiosis among commensal and pathogenic bacteria. It leads to demineralization of the tooth surface within an ecosystem of high density and diversity, known as dental biofilm (plaque), with increased acid production from microbial action of bacteria after intake of dietary fermentable carbohydrates 
(Nyvad et al., 2013; Kaur et al., 2017; Al-Dulaijan et al., 2018). A biofilm (plaque) is an ecological environment formed on the surface by microbial community and is made of self-produced extracellular polymeric substances (EPS) matrix consisting of protein, polysaccharides, and nucleic acid (Liu and $\mathrm{Yu}, 2017$; Ye et al., 2019). According to the ecological plaque hypothesis, both the related bacteria and ecological changes caused by other factors can interfere with the ecological balance between the host and microbes (Anderson et al., 2018).

Streptococcus mutans, a Gram-positive bacterium in oral cavity, causes dysbiosis in this symbiotic ecosystem, although it is not solely responsible for the disease progression. It is considered as the most relevant bacteria in the transition of non-pathogenic commensal oral microbiota to biofilms which contribute to the dental caries process (Martins et al., 2018). S. mutans has developed multiple mechanisms to colonize the tooth surface and form bacterial plaque biofilm (Ren et al., 2016; Hu et al., 2018b). The ability of this bacterium to produce organic acids through various carbohydrate metabolism processes (acidogenicity) and survive in low $\mathrm{pH}$ environment (aciduricity) are major virulence factors in biofilm and lead to the development to dental caries (Cai et al., 2017; Chakraborty and Burne, 2017). The biofilm phenotype is physiologically and functionally distinct from the planktonic bacteria. Bacteria in the biofilm exhibit reduced metabolic activity and physiology. The biofilm structure serves as a physical barrier which limits penetration of antimicrobial agents into the deep layers of biofilm. Thus, bacteria growing in a biofilm increase its tolerance to antibiotics and immune resistance to the host ( $\mathrm{Hu}$ et al., 2018a; Kuang et al., 2018; Ong et al., 2018). Since reckless and continuous use of antibiotics has led to a rapid increase in antibiotic resistance to conventional therapies, there is an urgent need to develop novel antimicrobial agents in order to inhibit biofilm formation.

Natural plant products, mainly phytochemicals and their derivatives have been used as major sources of effective therapeutic agents throughout history and are considered as alternatives to antibacterial agents. Their advantages include relative inexpensiveness; abundant sources (such as fruits, seeds, and vegetables); low levels of cytotoxicity; high chemical diversity and biochemical specificity; and less prone toward developing resistance to antibiotics (Jeon et al., 2011; Abreu et al., 2016; Borges et al., 2016). Cinnamaldehyde, an $\alpha, \beta$-unsaturated aromatic aldehyde, is a major component in Chinese cinnamon essential oil (Table 1; Ribeiro et al., 2018). It is widely used as a flavoring agent in the food, beverages, and perfume industries (Adams et al., 2004; Lee and Balick, 2005). Cinnamaldehyde has been reported to be effective against Gram-positive and Gramnegative bacterial biofilms, such as those formed by Pseudomonas aeruginosa and Staphylococcus aureus (Zhang et al., 2014; Topa et al., 2018). Therefore, in the present study, we investigated the antimicrobial activity of cinnamaldehyde on the biofilm formed by $S$. mutans at sub-MIC levels. This study may aid the development of a natural product as a novel therapeutic agent to counteract the virulence effect of $S$. mutans; thus, cinnamaldehyde has the potential to be used in treatment of dental caries.
TABLE 1 | Chemical structure and molecular properties of cinnamaldehyde.

\section{Cinnamaldehyde}

Chemical structure
Molecular weight (g/mol)
logP (octanol-water partition coefficient)
n-ROTB (number of rotable bonds)
TPSA (topological polar surface area)

\section{MATERIALS AND METHODS}

\section{Bacterial Strain and Growth Condition}

Streptococcus mutans UA159 strain and Streptococcus sanguinis SK36 strain were provided by Laboratory of Oral Microbiota and Systemic Diseases, Shanghai Ninth People's Hospital, Shanghai Jiao Tong University School of Medicine. S. mutans and S. sanguinis were grown in Brain Heart Infusion Broth (BHI; Difco Laboratories, Sparks, MD, United States) at $37^{\circ} \mathrm{C}$ under anaerobic conditions $\left(80 \% \mathrm{~N}_{2}, 10 \% \mathrm{CO}_{2}\right.$, and $\left.10 \% \mathrm{H}_{2}\right)$.

Determination of Minimum Inhibitory Concentration (MIC) and Minimum Bactericidal Concentration (MBC)

The MIC and MBC of cinnamaldehyde against planktonic S. mutans were determined by the reference protocol of the Clinical and Laboratory Standards Institute (2012) broth method. The cinnamaldehyde (Sigma-Aldrich) was diluted in $0.5 \%$ dimethyl sulfoxide (DMSO) and tested at final concentrations of 250-4000 $\mu \mathrm{g} / \mathrm{mL}$. Bacterial suspensions $\left(5 \times 10^{5} \mathrm{CFU} / \mathrm{mL}\right)$ were added and then incubated at $37^{\circ} \mathrm{C}$ for $24 \mathrm{~h}$. To validate the methodology used in this study, we used a blank control (sterile culture medium, without cinnamaldehyde and suspensions of microorganisms) and a vehicle control (sterile culture medium with DMSO). The MIC was determined as the lowest drug concentration that inhibited visible bacterial growth. The MBC was defined as the lowest concentration that yielded no colony growth by subculturing on agar plates. Each experiment was performed with triplicate samples at each time point. The results correspond to three experiments independently.

\section{Growth Curve Assay}

The overnight culture of S. mutans was used to anaerobically inoculate a fresh BHI culture with different concentrations of cinnamaldehyde $(0,62.5,125,250,500$, and $1000 \mu \mathrm{g} / \mathrm{mL})$ at $37^{\circ} \mathrm{C}$ anaerobically for $24 \mathrm{~h}$. Chlorhexidine $(0.2 \%)$ was used as positive control. The optical density at $600 \mathrm{~nm}\left(\mathrm{OD}_{600 \mathrm{~nm}}\right)$ was measured by a spectrophotometer (UV1601, Shimadzu, Japan) every $3 \mathrm{~h}$ throughout incubation. Each experiment was performed with triplicate samples at each time point. The results correspond to three experiments independently.

\section{Crystal Violet Assay}

Crystal violet (CV) assay was used to provide an overall assessment of biofilm biomass in a 96-well microtiter plate 
(Bedran et al., 2014). An overnight culture adjusting the $\mathrm{OD}_{600 \mathrm{~nm}}$ to $0.1\left(10^{8} \mathrm{CFU} / \mathrm{mL}\right)$ was added to $180 \mu \mathrm{L}$ of fresh BHI liquid medium supplemented with $0.2 \%$ sucrose in each flat-bottom well with different concentrations of cinnamaldehyde $(0,62.5$, 125,250 , and $500 \mu \mathrm{g} / \mathrm{mL}$ ). The dual-species biofilm was formed as previously described in detail (Guo et al., 2019). The positive control was set as chlorhexidine $(0.2 \%)$. The plates were then incubated at $37^{\circ} \mathrm{C}$ for different times $(4,24 \mathrm{~h})$ without agitation. After incubation, the growth medium was gently removed, washed three times with sterile phosphate-buffered saline (PBS) and replaced with $100 \mu \mathrm{L} \mathrm{CV}$. The plates were incubated for $10 \mathrm{~min}$ at room temperature. The excess $\mathrm{CV}$ solution was removed, and wells were rinsed three times with PBS and the bound CV was dissolved by adding $100 \mu \mathrm{L} 95 \%$ ethanol. The absorbance of the solution was measured at a wavelength of $550 \mathrm{~nm}$ by microplate reader. Each experiment was performed with triplicate samples at each time point. The results correspond to three experiments independently.

\section{MTT Assay}

MTT [3-(4,5-dimethylthiazol-2-yl)-2,5-diphenyltetrazolium bromide] assay was used to assess the metabolic activities of viable biofilm cells (He et al., 2012). The biofilm was formed as described above. After incubation, the growth medium was gently removed, carefully washed three times with sterile PBS and replaced with $100 \mu \mathrm{L}$ of MTT $(5 \mathrm{mg} / \mathrm{mL})$ for $3 \mathrm{~h}$ in a dark place. Next, the supernatant was discarded and $100 \mu \mathrm{L}$ of lysing solution [10\% (v/v) sodium dodecyl sulfate and $50 \%(\mathrm{v} / \mathrm{v})$ dimethylformamide in distilled water] was added to dissolve the biofilm for $3 \mathrm{~h}$ at room temperature before reading the $\mathrm{OD}_{590 \mathrm{~nm}}$ values. Wells contained no cells were used as blank, and wells with chlorhexidine $(0.2 \%)$ were used as positive controls. Each experiment was performed with triplicate samples at each time point. The results correspond to three experiments independently.

\section{CLSM Analysis}

Streptococcus mutans biofilms were cultured on glass slides with different concentrations of cinnamaldehyde $(0,125,250$, and $500 \mu \mathrm{g} / \mathrm{mL}$ ) for $24 \mathrm{~h}$ at $37^{\circ} \mathrm{C}$. The biofilms formed on each sheet were washed three times with saline to remove unbound cells and stained for $30 \mathrm{~min}$ in the dark with L7012 LIVE/DEAD BacLight TM bacterial cells (Molecular Probes Inc., Eugene, OR, United States) containing SYTO 9 dye and propidium iodide. A confocal laser scanning microscope (Leica TCS SP2, Leica microsystems, Germany) was used to record image stacks in five random locations. Five confocal data sets were recorded at $40 \times$ magnification with a numerical aperture of 1.25. In each experiment, the exciting laser intensity, background level, contrast, and electronic zoom were maintained at the same level.

\section{Bacterial Surface Hydrophobicity Assay}

Streptococcus mutans surface hydrophobicity was determined by microbial adhesion to hydrocarbon (Rosenberg, 2006). Briefly, S. mutans was adjusted to an optical density $\left(\mathrm{OD}_{600 \mathrm{~nm}}\right)$ of approximately 0.5 . After incubation at $37^{\circ} \mathrm{C}$ for 0 or $30 \mathrm{~min}$ with same concentrations $(0,125,250$, and $500 \mu \mathrm{g} / \mathrm{mL})$ of cinnamaldehyde as above under an aerobic condition, the tubes were centrifuged at $5000 \times g$ for $5 \mathrm{~min}$ at $4^{\circ} \mathrm{C}$, washed twice with sterile PBS, and resuspended in the same buffer. Absorbance was measured at $550 \mathrm{~nm}$ (recorded as $\mathrm{OD}_{1}$ ). Then, the tube was vigorously shaken after adding $20 \%$ (v/v) xylene. The mixture was left to settle until the aqueous phase separated from the organic phase. Absorbance of the aqueous phase was measured at $550 \mathrm{~nm}$ (recorded as $\mathrm{OD}_{2}$ ). The percent hydrophobicity was calculated by the following equation: $\mathrm{H}=\left(\mathrm{OD}_{1}-\mathrm{OD}_{2}\right) / \mathrm{OD}_{2} \times 100 \%$. The final hydrophobicity was determined using the difference between values at $0 \mathrm{~min}\left(\mathrm{H}_{1}\right)$ and $30 \mathrm{~min}\left(\mathrm{H}_{2}\right)$. Bacterial surface hydrophobicity assays were performed in triplicate independent.

\section{Bacterial Aggregation Assay}

Aggregation experiments were performed as previously described with minor modifications (Xu et al., 2012). Briefly, an overnight of $S$. mutans suspension was harvested by centrifugation at $12,000 \times g$ for $30 \mathrm{~s}$, washed twice with PBS, and resuspended in PBS to an optical density $\left(\mathrm{OD}_{600 \mathrm{~nm}}\right)$ of approximately 0.5 , determined by using a spectrophotometer. The initial $\mathrm{OD}_{600 \mathrm{~nm}}$ was recorded and the samples with same concentrations $(0,125,250$, and $500 \mu \mathrm{g} / \mathrm{mL})$ of cinnamaldehyde as above were incubated at $37^{\circ} \mathrm{C}$ for $2 \mathrm{~h}$. The percentage of aggregation was calculated by the following equation: Aggregation rate $=\left(\mathrm{OD}_{\text {Initial }}-\mathrm{OD}_{2 \mathrm{~h}}\right) /\left(\mathrm{OD}_{\text {Initial }}-\mathrm{OD}_{\text {Blank }}\right) \times 100 \%$. Bacterial aggregation assays were performed in triplicate independent.

\section{Glycolytic pH Drop}

The effect of cinnamaldehyde on S. mutans glycolysis was measured as described elsewhere (Belli and Marquis, 1991). Briefly, S. mutans was harvested at mid-logarithmic phase, washed with a salt solution $\left(50 \mathrm{mM} \mathrm{KCl}+1 \mathrm{mM} \mathrm{MgCl}_{2}\right)$, and resuspended in the same salt solution with same concentrations of cinnamaldehyde $(0,125,250$, and $500 \mu \mathrm{g} / \mathrm{mL})$ as above. Glucose was added to a final concentration of $1 \%(\mathrm{w} / \mathrm{v})$ and the initial $\mathrm{pH}$ of the mixtures was then adjusted to $7.2-7.4$ with $0.2 \mathrm{M}$ $\mathrm{KOH}$. The decrease in $\mathrm{pH}$ by glycolytic activity of $S$. mutans was monitored at $10 \mathrm{~min}$ intervals over a period of $120 \mathrm{~min}$. The experiments were repeated for three times independently.

\section{Acid Tolerance Assay}

The role of cinnamaldehyde on the acid tolerance of S. mutans was evaluated by measuring the viability of bacteria after 120 min exposure at pH 5.0 (Svensäter et al., 1997). S. mutans were harvested at the mid-logarithmic phase and collected by centrifugation. The cells were resuspended in TYEG (containing $10 \%$ tryptone, $5 \%$ yeast extract, $3 \% \mathrm{~K}_{2} \mathrm{HPO}_{4}$, and $1 \%$ glucose) medium buffered with $40 \mathrm{mM}$ phosphate-citrate buffer $(\mathrm{pH}$ 5.0) with same concentrations $(0,125,250$, and $500 \mu \mathrm{g} / \mathrm{mL})$ of cinnamaldehyde as above, and incubated at $37^{\circ} \mathrm{C}$ for $2 \mathrm{~h}$. Samples were removed for viable counts. We counted the number of colony on plates, expressed as $\mathrm{CFU} / \mathrm{mL}$ after diluting the sample. The number of colonies was calculated following logtransformation, to normalize the data. The experiments were repeated for three times independently. 


\section{RNA Isolation, Reverse Transcription, and Quantitative Real-Time PCR}

To evaluate the effect of cinnamaldehyde on the expression of virulence genes of S. mutans, the $24 \mathrm{~h}$ biofilms formed with different concentrations of cinnamaldehyde $(0,250$, and $500 \mu \mathrm{g} / \mathrm{mL}$ ) were harvested, resuspended in TRIzol reagent (Sigma-Aldrich). Total RNA extractions were performed according to the manufacturer's instructions. Purified RNA was dissolved in $20 \mu \mathrm{L}$ of DEPC-treated water and stored at $-80^{\circ} \mathrm{C}$ until required for cDNA labeling. A cDNA synthesis kit (Takara, Dalian, China) was used to generate cDNAs. The reverse transcription reaction mixture $(20 \mu \mathrm{L})$, consisting of $4 \mu \mathrm{L}$ of $5 \times$ Buffer (containing dNTPs and $\mathrm{Mg}^{2+}$ ), $1 \mu \mathrm{L}$ of PrimeScript RT EnzymeMix I, $1 \mu \mathrm{L}$ of Oligo (dT) primer $(50 \mu \mathrm{M}), 1 \mu \mathrm{L}$ of random hexamers $(100 \mu \mathrm{M})$, and $1 \mu \mathrm{g}$ of RNA sample, was incubated at $37^{\circ} \mathrm{C}$ for $15 \mathrm{~min}$ and the reaction was terminated at $85^{\circ} \mathrm{C}$ for $5 \mathrm{~s}$, according to the manufacturer's instructions. The cDNA samples were stored at $-20^{\circ} \mathrm{C}$ until used.

The real-time PCR reaction mixture $(20 \mu \mathrm{L})$ contained SYBRGreen PCR Master Mix (Takara), $5 \mu \mathrm{L}$ of template cDNA, and $0.5 \mu \mathrm{M}$ appropriate forward and reverse PCR primers. The PCR conditions included an initial denaturation at $95^{\circ} \mathrm{C}$ for $5 \mathrm{~min}$, followed by 40 cycles of denaturation at $95^{\circ} \mathrm{C}$ for $15 \mathrm{~s}$, annealing and extension at $55^{\circ} \mathrm{C}$ for $15 \mathrm{~s}$. The resulting cDNA and negative control were amplified using an Applied Biosystems 7900HT Fast Real-Time PCR System (Applied Biosystems). The primer sequences in this study are listed in Table 2. The expression levels of all the tested genes (Table 2) were normalized using the 16S rRNA gene of S. mutans (GenBank accession No. X58303) as an internal standard. The cycle threshold $\left(C_{t}\right)$ values are defined as the cycle in which fluorescence becomes detectable above the background fluorescence, and is inversely proportional to the logarithm of the initial number of template molecules. The fold changes in gene expression were using the $\Delta \Delta C_{\mathrm{t}}$ method. Each experiment was performed with triplicate samples at each time point. The results correspond to three experiments independently.

\section{Statistical Analysis}

All data are expressed as mean \pm standard deviation. One-way analysis of variance (ANOVA) with Dunnett's post hoc test was used to calculate the significance of the difference between the biofilms formed by S. mutans with or without cinnamaldehyde under the tested conditions (SPSS 15.0 software, United States). $P<0.05$ was considered statistically significant.

\section{RESULTS}

\section{Antibacterial Activity of Cinnamaldehyde on Planktonic S. mutans}

The MIC and the MBC of cinnamaldehyde against planktonic S. mutans were 1000 and $2000 \mu \mathrm{g} / \mathrm{mL}$, respectively (Figures 1A,B). The results of growth curve assay confirmed that cinnamaldehyde significantly inhibited the growth of S. mutans at the concentration of $1000 \mu \mathrm{g} / \mathrm{mL}$. Compared to the control group, there was no significant alteration in the growth curve of $S$. mutans with cinnamaldehyde under $500 \mu \mathrm{g} / \mathrm{mL}$ of concentration as shown in Figure 1C.

\section{Cinnamaldehyde Suppresses Biofilm Biomass and Metabolic Activity}

The overall biomass of biofilms was quantified by the crystal violet $(\mathrm{CV})$ assay at the concentration ranging up to $500 \mu \mathrm{g} / \mathrm{mL}$ of

TABLE 2 | Nucleotide sequences of primers used in this study.

\begin{tabular}{|c|c|c|c|}
\hline Gene* & Description & Primer sequence $\left(5^{\prime}-3^{\prime}\right)$ & $\begin{array}{l}\text { Amplicon } \\
\text { size (bp) }\end{array}$ \\
\hline $16 S$ rRNA & Normalizing internal standard & $\begin{array}{l}\text { F: CCTACGGGAGGCAGCAGTAG } \\
\text { R: CAACAGAGCTTTACGATCCGAAA }\end{array}$ & 100 \\
\hline gtfB & Water insoluble glucan production & $\begin{array}{l}\text { F: AGCAATGCAGCCAATCTACAAAT } \\
\text { R: ACGAACTTGCCGTTATTGTCA }\end{array}$ & 95 \\
\hline gtfC & Water soluble and insoluble glucan production & $\begin{array}{l}\text { F: GTGCGCTACACCAATGACAGAG } \\
\text { R: GCCTACTGGAACCCAAACACCTA }\end{array}$ & 107 \\
\hline$g b p B$ & Glucan binding protein & $\begin{array}{l}\text { F: ATGGCGGTTATGGACACGTT } \\
\text { R: TTTGGCCACCTTGAACACCT }\end{array}$ & 50 \\
\hline vich & Response regulator & $\begin{array}{l}\text { F: TGACACGATTACAGCCTITGATG } \\
\text { R: CGTCTAGTTCTGGTAACATTAAGTCCAATA }\end{array}$ & 100 \\
\hline $\mathrm{CiaH}$ & Response regulator & $\begin{array}{l}\text { F: CGTCATCAATAATGTCAATGCCTTC } \\
\text { R: TACCTTAACTGTCACTGTCCGATAC }\end{array}$ & 138 \\
\hline relA & Guanosine tetra (penta)-phosphate synthetase & $\begin{array}{l}\text { F: ACAAAAAGGGTATCGTCCGTACAT } \\
\text { R: AATCACGCTTGGTATTGCTAATTG }\end{array}$ & 100 \\
\hline
\end{tabular}

*Based on the NCBI S. mutans genome database. 


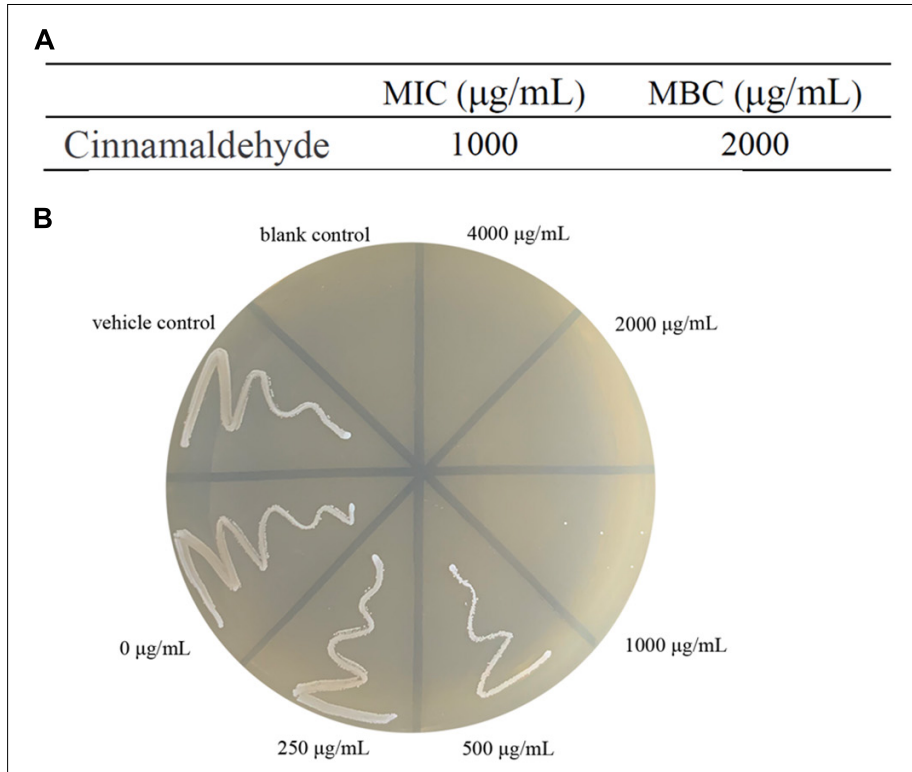

C

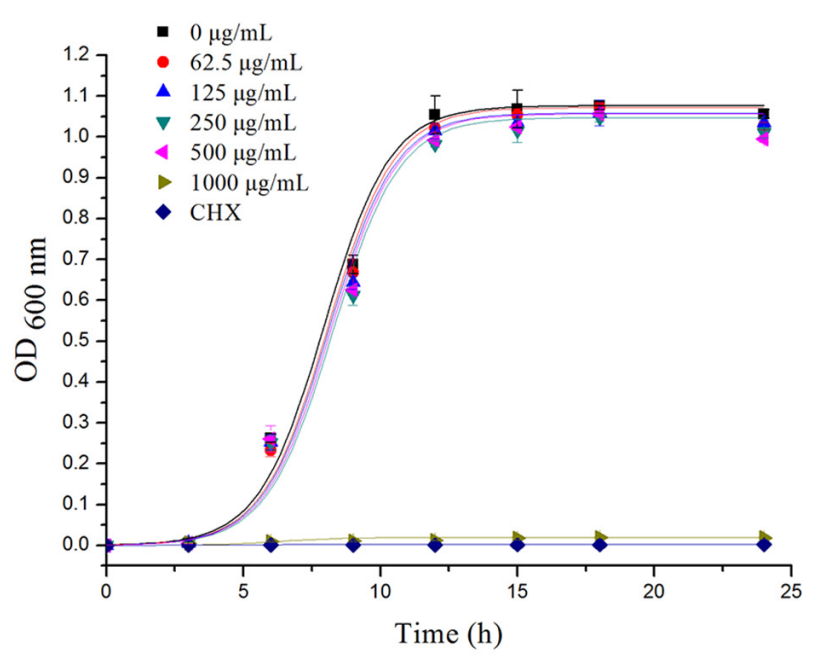

FIGURE 1 | Antibacterial Activity of Cinnamaldehyde. (A) MIC and MBC values of cinnamaldehyde against planktonic S. mutans. (B) The number of colonies on BHI agar. (C) Growth curve of planktonic S. mutans with different concentrations of cinnamaldehyde. ${ }^{*} P<0.05$, ${ }^{* *} P<0.01$, significantly different from the control group.

cinnamaldehyde. There were significant differences in the overall biomass of biofilms at both $4 \mathrm{~h}$ and $24 \mathrm{~h}$ time points for different concentrations of cinnamaldehyde (except for $62.5 \mu \mathrm{g} / \mathrm{mL}$ ) compared with the control group (Figure 2A). At 4 h, S. mutans exhibited $\mathrm{OD}_{550 \mathrm{~nm}}$ values of $0.995 \pm 0.099$. In the presence of cinnamaldehyde, the $\mathrm{OD}_{550 \mathrm{~nm}}$ values after $4 \mathrm{~h}$ incubation were $0.917 \pm 0.007$ at $125 \mu \mathrm{g} / \mathrm{mL}, 0.820 \pm 0.018$ at $250 \mu \mathrm{g} / \mathrm{mL}$, and $0.551 \pm 0.036$ at $500 \mu \mathrm{g} / \mathrm{mL}$ concentration. Similar trends were observed after $24 \mathrm{~h}$ of incubation. With increasing concentrations of cinnamaldehyde, the biomass of biofilms exhibited $\mathrm{OD}_{550 \mathrm{~nm}}$ values that decreased from $2.879 \pm 0.093$ at $125 \mu \mathrm{g} / \mathrm{mL}$ to $1.182 \pm 0.127$ at $500 \mu \mathrm{g} / \mathrm{mL}$. The biomass of dual-species biofilm was also inhibited by cinnamaldehyde as shown in Figure 2C. The manner of inhibition was similar to that of the S. mutans single-species biofilm.

The metabolic activity of biofilms was quantified by the MTT assay with the same concentrations of cinnamaldehyde as mentioned above. The results showed that cinnamaldehyde decreased the biofilm metabolism at both time points compared to the control group and also confirmed the crystal violet assay data (Figure 2B). The metabolic activity of biofilms exhibited $\mathrm{OD}_{590 \mathrm{~nm}}$ values of $0.162 \pm 0.004$ and $0.605 \pm 0.019$ at 4 and $24 \mathrm{~h}$, respectively, whereas in the presence of cinnamaldehyde, the values decreased from $0.151 \pm 0.003$ at $125 \mu \mathrm{g} / \mathrm{mL}$ to $0.125 \pm 0.003$ at $500 \mu \mathrm{g} / \mathrm{mL}$ after $4 \mathrm{~h}$ of incubation and decreased from $0.484 \pm 0.020$ at $125 \mu \mathrm{g} / \mathrm{mL}$ to $0.188 \pm 0.010$ at $500 \mu \mathrm{g} / \mathrm{mL}$ after $24 \mathrm{~h}$ of incubation. Cinnamaldehyde also inhibited the metabolic activity of dualspecies biofilm in a manner similar to its inhibition of the S. mutans single-species biofilm (Figure 2D). These results demonstrated that cinnamaldehyde at the concentrations ranging from 125 to $500 \mu \mathrm{g} / \mathrm{mL}$ can effectively reduce biofilm biomass and metabolic activity of $S$. mutans single and dual-species biofilms at different incubation time points during biofilm formation.

\section{Confocal Microscopic Observation of Biofilm}

The biofilm images formed with different concentrations of cinnamaldehyde after $24 \mathrm{~h}$ of incubation were observed using a confocal laser scanning microscope (Figure 3). The images reflect different green (live cells) and red (dead cells) fluorescence intensities. In the absence of cinnamaldehyde, the biofilm had a uniform distribution with a relatively dense structure and complete coverage of the surface (Figure 3A). Following treatment with cinnamaldehyde, the biofilms were highly dispersed and visibly loose (Figures 3B-D). Cinnamaldehyde decreased the surface area visibly covered by the biofilm, which consequently led to significant reduction in the biofilm biomass.

\section{Cinnamaldehyde Increased Surface Hydrophobicity, Reduced Aggregation}

The hydrophobicity of the bacterial surfaces was determined by measuring the percentage of their adherence to hydrocarbons. Cinnamaldehyde increased S. mutans surface hydrophobicity as shown in Figure 4A. The S. mutans surface hydrophobicity rates with different concentrations of cinnamaldehyde $(125,250$, and $500 \mu \mathrm{g} / \mathrm{mL}$ ) were $13.40 \pm 1.77 \%, 14.39 \pm 0.62 \%$ and $17.56 \pm 0.56 \%$, respectively; which were substantially higher than that of the control group (6.54 $\pm 0.29 \%)$. As shown in Figure 4B, the aggregation rate of $S$. mutans reached $23.39 \pm 2.61 \%$ after $2 \mathrm{~h}$ incubation. A dose-dependent decrease in bacterial aggregation was observed with different concentrations of cinnamaldehyde. These results indicated that cinnamaldehyde plays an important role in hydrophobicity and aggregation. 

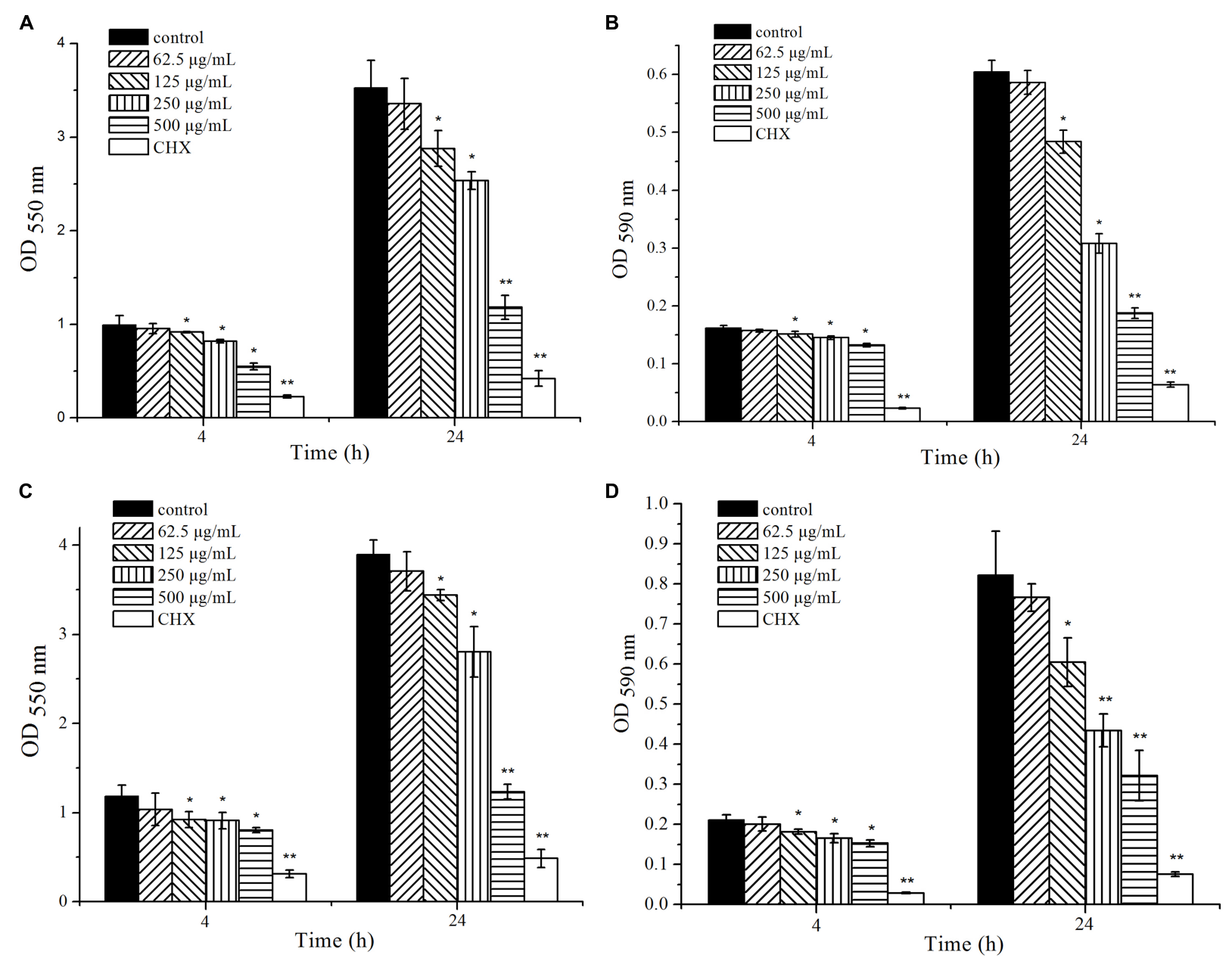

FIGURE 2 | Effect of cinnamaldehyde on overall biomass and metabolic activity of single-species and dual-species biofilm formation at 4 and $24 \mathrm{~h}$ time points. (A) overall biomass of $S$. mutans biofilm (B) metabolic activity of $S$. mutans biofilm (C) overall biomass of $S$. mutans and $S$. sanguinis biofilm (D) metabolic activity of S. mutans and $S$. sanguinis biofilm. ${ }^{*} P<0.05,{ }^{* *} P<0.01$, significantly different from the control group at 4 and $24 \mathrm{~h}$ time points.

\section{Cinnamaldehyde Inhibit the Acidogenicity and Acidurity}

The effects of cinnamaldehyde on acid production by $S$. mutans were evaluated using glycolytic $\mathrm{pH}$ drop assay. S. mutans was cultured in the presence of various concentrations of cinnamaldehyde, and the $\mathrm{pH}$ change was measured. As shown in Figure 5A, the $\mathrm{pH}$ decreased from $7.21 \pm 0.01$ to $4.35 \pm 0.05$ after $120 \mathrm{~min}$ of incubation in the control group. The terminal $\mathrm{pH}$ increased this acidic $\mathrm{pH}(4.35 \pm 0.05)$ to $5.29 \pm 0.09$, $5.56 \pm 0.02,6.06 \pm 0.11$ after treatment with cinnamaldehyde $(125,250$, and $500 \mu \mathrm{g} / \mathrm{mL})$. The maximum initial $\mathrm{pH}$ drop recorded within first 10 min of incubation was observed in the control group maximum (from $7.21 \pm 0.01$ to $5.49 \pm 0.13$ ). However, $500 \mu \mathrm{g} / \mathrm{mL}$ cinnamaldehyde showed minimum initial $\mathrm{pH}$ drop from $7.21 \pm 0.01$ to $6.85 \pm 0.14$.

The effects of cinnamaldehyde on acid tolerance of $S$. mutans were evaluated and the results are shown in Figure 5B. Compared with the control group, fewer bacterial colonies were formed after treatment with cinnamaldehyde. The survival rates of
S. mutans at $\mathrm{pH} 5.0$ were significantly reduced in the presence of cinnamaldehyde $(125 \mu \mathrm{g} / \mathrm{mL}, 250 \mu \mathrm{g} / \mathrm{mL}, 500 \mu \mathrm{g} / \mathrm{mL}, P<0.05)$. These results indicated that cinnamaldehyde inhibits $S$. mutans acidogenicity and acidurity.

\section{Gene Expressions Were Down-Regulated by Cinnamaldehyde Treatment}

To gain insight into biofilm-related gene expression, realtime PCR analysis was used to quantify the effect of 250 and $500 \mu \mathrm{g} / \mathrm{mL}$ cinnamaldehyde on the biofilms formed by $S$. mutans. Among the studied genes, four genes were found to be involved in extracellular polysaccharide synthesis ( $g t f B$, $g t f C, g t f D$, and $g b p B$ ). Three genes were found to be related to two-component signal transduction system (comDE, vicR, and $c i a H)$. And $l d h$ and relA genes encode lactic acid production and guanosine tetra (penta)-phosphate synthetase/hydrolase, respectively. In general, all tested genes (Table 1) were down-regulated in the biofilms treated with 250 and $500 \mu \mathrm{g} / \mathrm{mL}$ cinnamaldehyde compared to the control group and the relative 


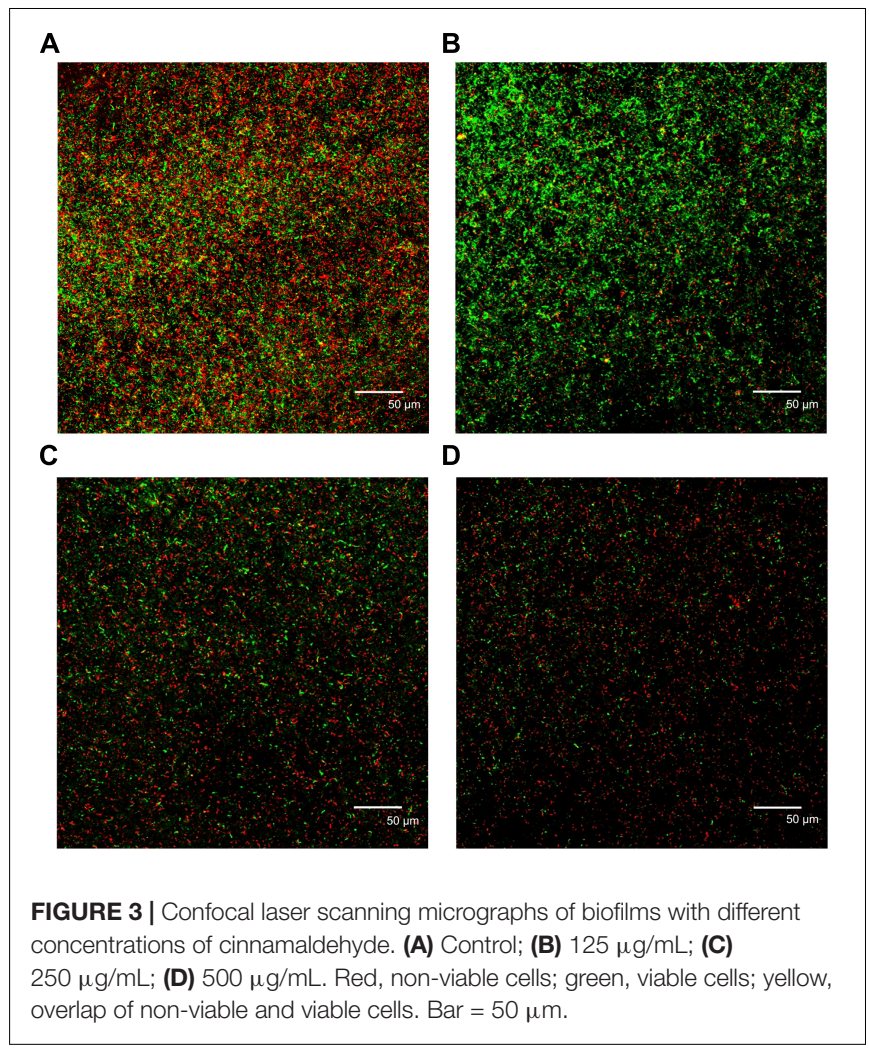

fold changes of gene transcripts decreased with increasing cinnamaldehyde concentration (Figure 6). After 250 and $500 \mu \mathrm{g} / \mathrm{mL}$ cinnamaldehyde treatment, expression of $\mathrm{gtfD}$ in S. mutans biofilms was significantly decreased by $0.0421-$, and 0.00380 fold, respectively. After cinnamaldehyde treatment, expression levels of other genes associated with biofilm formation were reduced in the range from 0.517 to 0.0819 fold at $250 \mu \mathrm{g} / \mathrm{mL}$ and from 0.273 to 0.00483 fold at $500 \mu \mathrm{g} / \mathrm{mL}$.

\section{DISCUSSION}

Dental caries is the most common oral diseases that results from a dysbiosis of tooth-associated biofilms. In recent years, the use of natural plant products for oral diseases has attracted increasing attention and has been widely studied (Kouidhi et al., 2015). In the present study, we selected the natural product, cinnamaldehyde, for investigating its antimicrobial activities against S. mutans biofilm. First, we determined that MIC and MBC of cinnamaldehyde against planktonic S. mutans UA159 were 1000 and $2000 \mu \mathrm{g} / \mathrm{mL}$, which was slightly different from previous studies. The MIC of cinnamaldehyde for $S$. mutans (ATCC 25175) was $>500 \mu \mathrm{M}$ by resazurin staining with BHI broth at $37^{\circ} \mathrm{C}$ in $5 \% \mathrm{CO}_{2}$ for $24 \mathrm{~h}$ (Polaquini et al., 2017). The MBC value for S. mutans (DMS20523) was $1728 \mu \mathrm{g} / \mathrm{mL}$ (= $13 \mathrm{mM}$ ) with TSB broth at $37^{\circ} \mathrm{C}$ for $1 \mathrm{~h}$ (Ribeiro et al., 2018). The difference may be caused by the use of different bacterial strains, culture media, conditions, and methods. Our results demonstrated that cinnamaldehyde did not significantly affect the bacterial growth rate at concentrations below $500 \mu \mathrm{g} / \mathrm{mL}$. We investigated the effect of cinnamaldehyde at sub-MIC levels on the development of dental caries by inhibiting S. mutans biofilm formation.

Biofilm formation can be divided into several processes, including the initial adherence to a solid surface, reversible attachment to that surface, production of extracellular polymeric substance (EPS), irreversible attachment, and maturation into a complex three-dimensional architecture. In our study, the CV and MTT assays showed that cinnamaldehyde attenuated the biofilm formation at initial adherence stage $(4 \mathrm{~h})$ and maturation stage $(24 \mathrm{~h})$ more effectively with increasing concentration increasing, ranging from 125 to $500 \mu \mathrm{g} / \mathrm{mL}$. CV assay was used for quantification of biofilm biomass, while the MTT assay was utilized to evaluate the metabolic activities of viable bacteria in biofilms. Importantly, cinnamaldehyde not only inhibited biofilm formation of $S$. mutans in a single-species model, but also inhibited dual-species biofilm by $S$. mutans and S. sanguinis in

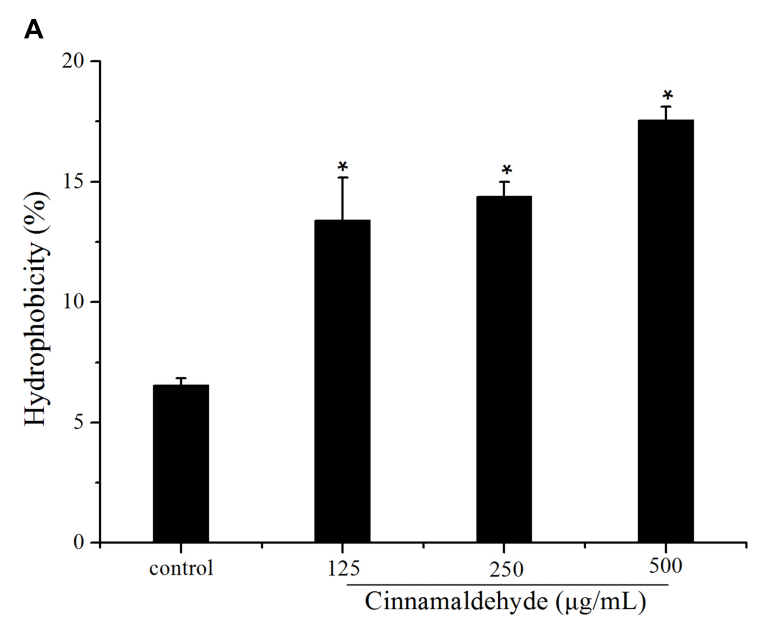

B

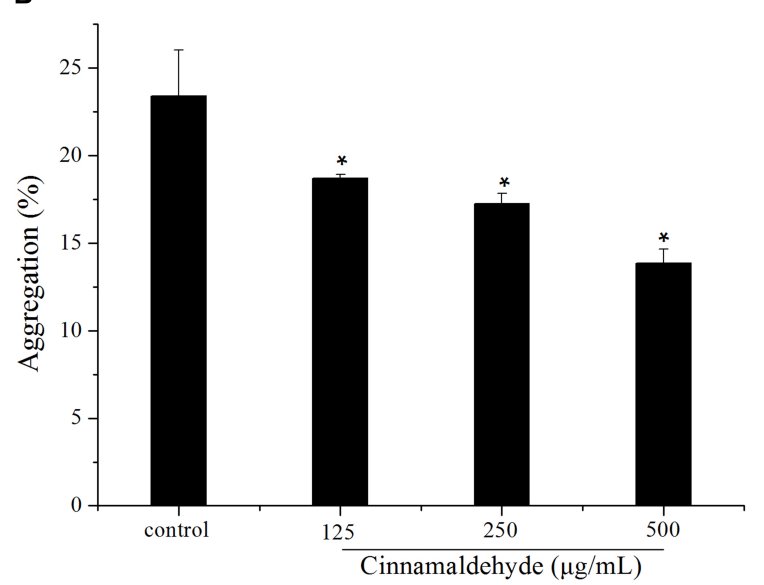

FIGURE 4 | Effect of cinnamaldehyde on hydrophobicity (A) and aggregation (B) of S. mutans. ${ }^{*} P<0.05$, significantly different from the control group. 

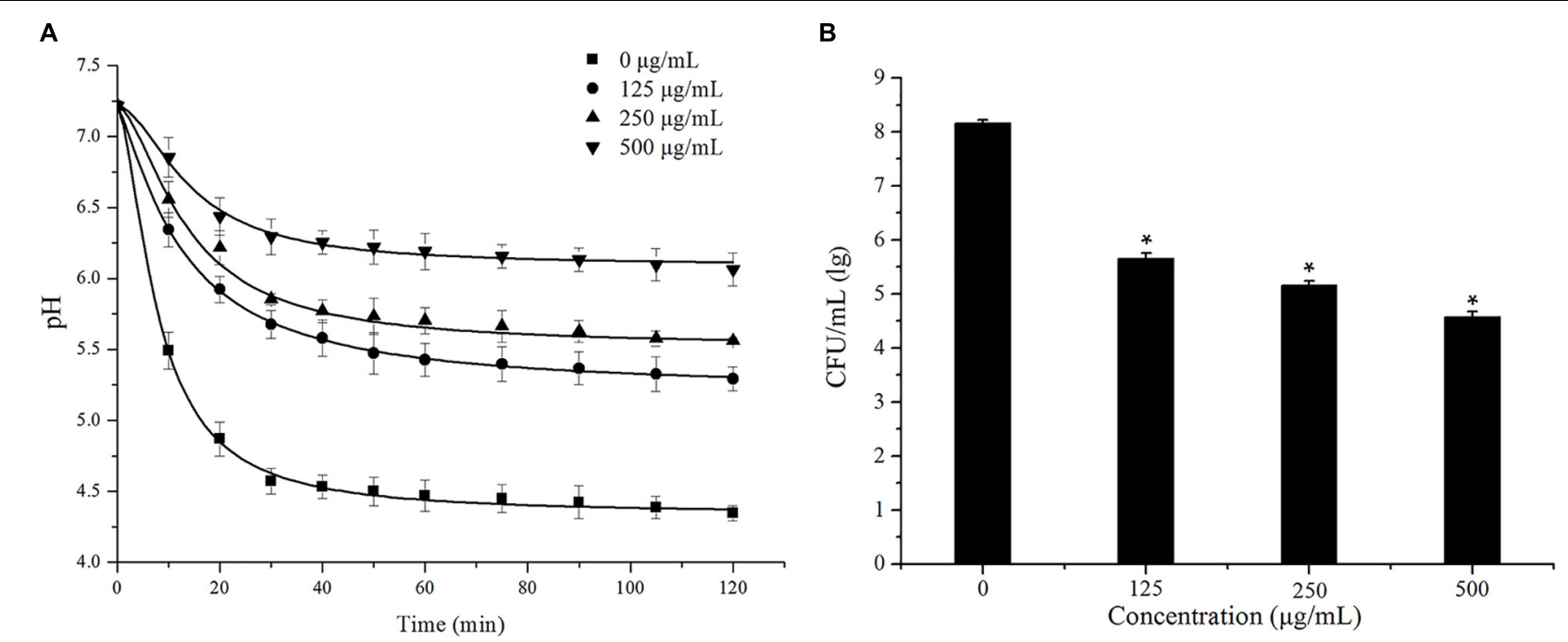

FIGURE 5 | Effect of cinnamaldehyde on acid production (A) and acid tolerance (B) of S. mutans. ${ }^{*} P<0.05$, significantly different from the control group.

similar trend. S. sanguinis is an early colonizer of tooth surfaces and forms biofilms with other species of microorganisms. S. mutans and S. sanguinis are predominant members in the dental plaque, which is often described as a dual-species biofilm model (Liu et al., 2011; Pereira et al., 2013; Li et al., 2014; Yoshida et al., 2014; Guo et al., 2019). Confocal imaging also confirmed that the biofilms were highly dispersed and visibly loose upon cinnamaldehyde treatment. These results suggested that unlike antibiotics, the biofilm decrease induced by cinnamaldehyde is not related to planktonic bacterial growth inhibition.

Bacterial properties, such as cell surface hydrophobicity and aggregation are important for adherence to the tooth surface,

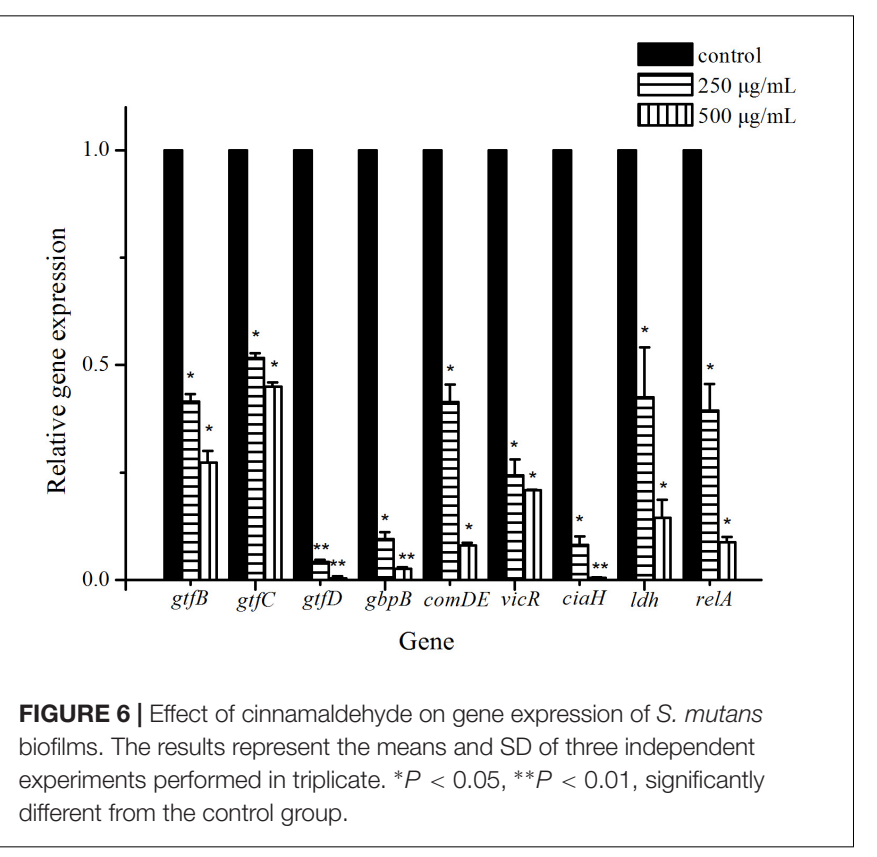

which is essential for dental biofilm formation and subsequent dental caries (Gibbons and van Houte, 1973; Matsumoto-Nakano et al., 2011). The adhesion of S. mutans includes a sucroseindependent mode, which primarily depends on hydrogen bonding and hydrophobic interactions between bacteria and the adhering surface (Hasan et al., 2015). Aggregation is a process through which a strain within the biofilm produces polymers to boost the integration of genetically identical strains (Nyenje et al., 2012). In this study, cinnamaldehyde increased the hydrophobicity and decreased the aggregation of S. mutans, which suggests that cinnamaldehyde might inhibit bacteria to adhere on a tooth surface, thereby reducing the biofilm formation, and this finding was consistent with previous studies (Yue et al., 2018).

The ability to produce acid (acidogenicity) and to tolerance to low $\mathrm{pH}$ (acidurance) are key physiological factors of $S$. mutans for the demineralization of the tooth surface and formation of dental caries of S. mutans (Kuramitsu, 1993; Banas, 2004). We investigated the effect of sub-MIC concentrations of cinnamaldehyde on acid production using a glycolysis $\mathrm{pH}$ drop assay. Glycolysis is the main pathway for acid production. The bacteria carry out glycolysis continuously by metabolizing a wide range of dietary carbohydrates, and finally form acids. The critical pH value of 5.0-5.5 is important for the balance between demineralization and remineralization of tooth enamel. If the surrounding solution $\mathrm{pH}$ caused by accumulation of acid is less than the critical $\mathrm{pH}$, tooth demineralization and subsequent initiation of dental caries occur (Pandit et al., 2013). Our results showed that with increasing concentrations of cinnamaldehyde, the initial rate of the $\mathrm{pH}$ drop gradually reduced and the final $\mathrm{pH}$ values were higher than the critical $\mathrm{pH}$ value. These findings suggest that cinnamaldehyde impairs in acidogenicity and prevents tooth demineralization, which may be due to the inhibition of the glycolytic enzymes for acid production. Acid tolerance is another main physiological factor associated with the 
cariogenic potential. Our result indicates that cinnamaldehyde decreases the survival rate of bacteria at $\mathrm{pH}$ 5.0. Additionally, the final $\mathrm{pH}$ values in the glycolytic $\mathrm{pH}$-drop assay also reflect acid tolerance (Gregoire et al., 2007). Therefore, it is apparent that cinnamaldehyde has a notable effect on the acid production and acid tolerance.

Finally, real-time PCR analysis was performed to evaluate the effect of cinnamaldehyde on the gene expressions of virulence factors in $S$. mutans. Differences in the expression of the various virulence genes provided information on their function in biofilm formation and helped in understanding the process. Our results showed that the expressions of all selected virulence genes were downregulated in the presence of cinnamaldehyde. Among them, GTFase synthesizes glucans which provide binding sites for bacterial adherence, biofilm formation and the development of caries. S. mutans has at least three GTF enzymes (GTFB, GTFC, and GTFD), according to the types of glucans they synthesize. GTFB (encoded by $g t f B)$ synthesizes water-insoluble polysaccharide containing $\alpha$ 1,3-linked glucans, which contributes to the scaffolding of the EPS matrix and facilitates cell aggregation in stable biofilms. GTFC (encoded by $g t f C$ ) catalyzes the synthesis of a mixture of water insoluble and alkali soluble glucan from sucrose, with both $\alpha-1,3$ and $\alpha-1,6$-linked glucans, which are required for plaque formation and structurally stable biofilms. GTFD (encoded by $g t f D)$ synthesizes water-soluble glucans containing $\alpha$-1,6-linked glucans, which allows interaction with salivary proteins in the pellicle (Veloz et al., 2016; De et al., 2018; Gabe et al., 2019). Mutant strains of $S$. mutans defective in $g t f$ genes, especially $g t f B$ and $g t f C$, are far less cariogenic than the wild type strains in vivo (Yamashita et al., 1993). The $g b p B$ gene, which encodes surface-associated glucan binding protein (GBPB), has affinity for glucans, mediating oral bacterial cell-cell aggregation, promoting bacterial adhesion and biofilm maturation process (Duque et al., 2011; Fujita et al., 2011). In our study, the reduction of these gene expressions may result in decreased production of extracellular polysaccharide and oral bacterial aggregation, thus inhibiting biofilm formation.

The two-component signal transduction system (TCS) plays important roles in response for multiple environmental stress responses, production of virulence factors, and biofilm formation. S. mutans UA159 contains 14 pairs of TCS, including VicRK, CiaRH and ComDE (Lévesque et al., 2007; He et al., 2008). The VicRK system was found to be involved in regulation of sucrose-dependent adhesion, competence development, and biofilm formation. $v i c R$ gene encodes a $\mathrm{VicR}$ response regulator, which is an essential part of VicRKX TCS. It is known to regulate a set of genes coding for synthesis of glucan matrix $(g t f B, g t f C, g t f D, g b p B)$, which are critical for adherence to a smooth tooth surface (Senadheera et al., 2005; Viszwapriya et al., 2017). CiaH/CiaR is another major TCSs related to biofilm formation, acid tolerance, and genetic competence. The deletion of the ciaH gene affects bacterial attachment, reduced sucroseindependent biofilm formation, abolished mutacin production, and diminished competence development (Tam et al., 2007; Wu et al., 2010). ComDE system, involved in competence regulation as well as bacteriocin production, is also the most common intraspecific cell-cell communication quorum sensing system in S. mutans. The quorum sensing system is an essential component of gene regulation networks responsible for the adaptation of bacteria in biofilms and stress responses. It can sense, respond to environmental fluctuations, and regulate a number of physiological activities including biofilm formation. It has a positive regulatory effect on the expression of biofilm-related genes such as $g t f B, g t f C$ and $g b p B$ in $S$. mutans, and inactivation of Com pathway results in biofilm defects (Li et al., 2008; Senadheera and Cvitkovitch, 2008; Kaur et al., 2017). Hence, down-regulation of comDE by cinnamaldehyde suppresses quorum sensing mechanism resulting in biofilm inhibition.

Lactate dehydrogenase ( $\mathrm{LDH}$, encoded by $l d h$ gene) is one of the most important enzymes in the process of glycolysis, which generate lactic acid in S. mutans. LDH and lactic acid facilitate $S$. mutans to dissolve tooth minerals and cause dental caries. Strains deficient in LDH display reduced cariogenicity (Fitzgerald et al., 1989; Zhang et al., 2016). relA gene encodes guanosine tetra (penta)-phosphate synthetase/hydrolase and is known to be involved in several processes, such as acid and oxidative stress tolerance mechanisms, and biofilm formation (Lemos et al., 2004; Liu et al., 2011). The suppression of these genes will impair acid tolerance and result in decreased virulence expressions.

\section{CONCLUSION}

In conclusion, our study demonstrated that cinnamaldehyde exhibits antimicrobial activity against $S$. mutans biofilm formation by modulating its hydrophobicity, aggregation, acid production, acid tolerance, and virulence gene expression. Therefore, cinnamaldehyde as a natural plant-derived compound may be useful to influence antimicrobial activity against S. mutans biofilm. Considering plaque biofilm is produced through multiple regulatory systems, further studies are required for the better understanding of the molecular mechanism underlying the inhibitory effect of cinnamaldehyde on S. mutans biofilm formation.

\section{DATA AVAILABILITY STATEMENT}

All datasets generated for this study are included in the manuscript/supplementary files.

\section{AUTHOR CONTRIBUTIONS}

WZ designed the project and supervised all the experiments. $\mathrm{ZYH}$ performed the experiments. $\mathrm{ZYH}, \mathrm{ZWH}$, and $\mathrm{WJ}$ analyzed the data and wrote the manuscript. All authors read and revised the manuscript.

\section{FUNDING}

This work was supported by a grant from the National Natural Science Foundation of China (81670992, 81600863, and 81300866). 


\section{REFERENCES}

Abreu, A. C., Saavedra, M. J., Simões, L. C., and Simões, M. (2016). Combinatorial approaches with selected phytochemicals to increase antibiotic efficacy against Staphylococcus aureus biofilms. Biofouling 32, 1103-1114. doi: 10.1080/ 08927014.2016.1232402

Adams, T. B., Cohen, S. M., Doull, J., Feron, V. J., Goodman, J. I., Marnett, L. J., et al. (2004). The FEMA GRAS assessment of cinnamyl derivates used as flavor ingredients. Food Chem. Toxicol. 42, 157-185. doi: 10.1016/j.fct.2003.08.021

Al-Dulaijan, Y. A., Cheng, L., Weir, M. D., Melo, M. A. S., Liu, H., Oates, T. W., et al. (2018). Novel rechargeable calcium phosphate nanocomposite with antibacterial activity to suppress biofilm acids and dental caries. J. Dent. 72, 44-52. doi: 10.1016/j.jdent.2018.03.003

Anderson, A. C., Rothballer, M., Altenburger, M. J., Woelber, J. P., Karygianni, L., Lagkouvardos, I., et al. (2018). In-vivo shift of the microbiota in oral biofilm in response to frequent sucrose consumption. Sci. Rep. 8:14202. doi: 10.1038/ s41598-018-32544-6

Banas, J. A. (2004). Virulence properties of Streptococcus mutans. Front. Biosci. 9:1267-1277. doi: 10.2741/1305

Bedran, T. B., Grignon, L., Spolidorio, D. P., and Grenier, D. (2014). Subinhibitory concentrations of triclosan promote Streptococcus mutans biofilm formation and adherence to oral epithelial cells. PLoS One 9:e89059. doi: 10.1371/journal. pone.0089059

Belli, W. A., and Marquis, R. E. (1991). Adaptation of Streptococcus mutans and Enterococcus hirae to acid stress in continuous culture. Appl. Environ. Microbiol. 57, 1134-1138.

Borges, A., Abreu, A. C., Dias, C., Saavedra, M. J., Borges, F., and Simões, M. (2016). New perspectives on the use of phytochemicals as an emergent strategy to control bacterial infections including biofilms. Molecules 21:E877. doi: 10 . 3390/molecules21070877

Cai, Y., Liao, Y., Brandt, B. W., Wei, X., Liu, H., Crielaard, W., et al. (2017). The fitness cost of fluoride resistance for different Streptococcus mutans strains in biofilms. Front. Microbiol. 8:1630. doi: 10.3389/fmicb.2017.01630

Chakraborty, B., and Burne, R. A. (2017). Effects of arginine on Streptococcus mutans growth, virulence gene expression, and stress tolerance. Appl. Environ. Microbiol. 83, e496-e417. doi: 10.1128/AEM.00496-17

Clinical and Laboratory Standards Institute (2012). Performance Standards for Antimicrobial Susceptibility Testing; Twenty-Second Informational Supplement. CLSI Document M100-S22. Wayne, PA: Clinical and Laboratory Standards Institute.

De, A., Jorgensen, A. N., Beatty, W. L., Lemos, J., and Wen, Z. T. (2018). Deficiency of MecA in Streptococcus mutans causes major defects in cell envelope biogenesis, cell division, and biofilm formation. Front. Microbiol. 9:2130. doi: 10.3389/fmicb.2018.02130

Duque, C., Stipp, R. N., Wang, B., Smith, D. J., Höfling, J. F., Kuramitsu, H. K., et al. (2011). Downregulation of GbpB, a component of the VicRK regulon, affects biofilm formation and cell surface characteristics of Streptococcus mutans. Infect. Immun. 79, 786-796. doi: 10.1128/IAI.00725-10

Fitzgerald, R. J., Adams, B. O., Sandham, H. J., and Abhyankar, S. (1989). Cariogenicity of alactate dehydrogenase-deficient mutant of Streptococcus mutans serotype c in gnotobiotic rats. Infect. Immun. 57, 823-826.

Fujita, K., Takashima, Y., Inagaki, S., Nagayama, K., Nomura, R., Ardin, A. C., et al. (2011). Correlation of biological properties with glucan-binding protein B expression profile in Streptococcus mutans clinical isolates. Arch. Oral Biol. 56, 258-263. doi: 10.1016/j.archoralbio.2010.09.018

Gabe, V., Kacergius, T., Abu-Lafi, S., Kalesinskas, P., Masalha, M., Falah, M., et al. (2019). Inhibitory effects of ethyl gallate on Streptococcus mutans biofilm formation by optical profilometry and gene expression analysis. Molecules 24:E529. doi: 10.3390/molecules24030529

Gibbons, R. J., and van Houte, J. (1973). On the formation of dental plaques. J. Periodontol. 44, 347-360. doi: 10.1902/jop.1973.44.6.347

Gregoire, S., Singh, A. P., Vorsa, N., and Koo, H. (2007). Influence of cranberry phenolics on glucan synthesis by glucosyltransferases and Streptococcus mutans acidogenicity. J. Appl. Microbiol. 103, 1960-1968. doi: 10.1111/j.1365-2672. 2007.03441.x

Guo, X., Liu, S., Zhou, X., Hu, H., Zhang, K., Du, X., et al. (2019). Effect of D-cysteine on dual-species biofilms of Streptococcus mutans and Streptococcus sanguinis. Sci. Rep. 9:6689. doi: 10.1038/s41598-019-43081-1
Hasan, S., Danishuddin, M., and Khan, A. U. (2015). Inhibitory effect of zingiber officinale towards Streptococcus mutans virulence and caries development: in vitro and in vivo studies. BMC Microbiol. 15:1. doi: 10.1186/s12866-0140320-5

He, X., Wu, C., Yarbrough, D., Sim, L., Niu, G., Merritt, J., et al. (2008). The cia operon of Streptococcus mutans encodes a unique component required for calcium-mediated autoregulation. Mol. Microbiol. 70, 112-126. doi: 10.1111/j. 1365-2958.2008.06390.x

He, Z., Wang, Q., Hu, Y., Liang, J., Jiang, Y., Ma, R., et al. (2012). Use of the quorum sensing inhibitor furanone C-30 to interfere with biofilm formation by Streptococcus mutans and its luxS mutant strain. Int. J. Antimicrob. Agents. 40, 30-35. doi: 10.1016/j.ijantimicag.2012.03.016

Hu, X., Huang, Y. Y., Wang, Y., Wang, X., and Hamblin, M. R. (2018a). Antimicrobial photodynamic therapy to control clinically relevant biofilm infections. Front. Microbiol. 9:1299. doi: 10.3389/fmicb.2018.01299

Hu, X., Wang, Y., Gao, L., Jiang, W., Lin, W., Niu, C., et al. (2018b). The impairment of methyl metabolism from luxS mutation of Streptococcus mutans. Front. Microbiol. 9:404. doi: 10.3389/fmicb.2018.00404

Jeon, J. G., Rosalen, P. L., Falsetta, M. L., and Koo, H. (2011). Natural products in caries research: current (limited) knowledge, challenges and future perspective. Caries Res. 45, 243-263. doi: 10.1159/000327250

Kaur, G., Balamurugan, P., and Princy, S. A. (2017). Inhibition of the quorum sensing system (ComDE Pathway) by aromatic 1,3-di-m-tolylurea (DMTU): cariostatic effect with fluoride in wistar rats. Front. Cell. Infect. Microbiol. 7:313. doi: 10.3389/fcimb.2017.00313

Kouidhi, B., Al Qurashi, Y. M., and Chaieb, K. (2015). Drug resistance of bacterial dental biofilm and the potential use of natural compounds as alternative for prevention and treatment. Microb. Pathog. 80, 39-49. doi: 10.1016/j.micpath. 2015.02.007

Kuang, X., Chen, V., and Xu, X. (2018). Novel approaches to the control of oral microbial biofilms. Biomed. Res. Int. 2018:6498932. doi: 10.1155/2018/ 6498932

Kuramitsu, H. K. (1993). Virulence factors of mutans streptococci: role of molecular genetics. Crit. Rev. Oral Biol. Med. 4, 159-176. doi: 10.1177/ 10454411930040020201

Lee, R., and Balick, M. J. (2005). Sweet wood-cinnamon and its importance as a spice and medicine. Explore 1, 61-64. doi: 10.1016/j.explore.2004.10.011

Lemos, J. A., Brown, T. A. Jr., and Burne, R. A. (2004). Effects of RelA on key virulence properties of planktonic and biofilm populations of Streptococcus mutans. Infect. Immun. 72, 1431-1440. doi: 10.1128/iai.72.3.1431-1440.2004

Lévesque, C. M., Mair, R. W., Perry, J. A., Lau, P. C., Li, Y. H., and Cvitkovitch, D. G. (2007). Systemic inactivation and phenotypic characterization of twocomponent systems in expression of Streptococcus mutans virulence properties. Lett. Appl. Microbiol. 45, 398-404. doi: 10.1111/j.1472-765X.2007.02203.x

Li, M., Huang, R., Zhou, X., Zhang, K., Zheng, X., and Gregory, R. L. (2014). Effect of nicotine on dual-species biofilms of Streptococcus mutans and Streptococcus sanguinis. FEMS Microbiol. Lett. 350, 125-132. doi: 10.1111/1574-6968.12317

Li, Y. H., Tian, X. L., Layton, G., Norgaard, C., and Sisson, G. (2008). Additive attenuation of virulence and cariogenic potential of Streptococcus mutans by simultaneous inactivation of the ComCDE quorum-sensing system and HK/RR11 two component regulatory system. Microbiology 154, 3256-3265. doi: 10.1099/mic.0.2008/019455-0

Liu, B. H., and Yu, L. C. (2017). In-situ, time-lapse study of extracellular polymeric substance discharge in Streptococcus mutans biofilm. Colloids Surf. B Biointerfaces 150, 98-105. doi: 10.1016/j.colsurfb.2016.11.031

Liu, C., Worthington, R. J., Melander, C., and Wu, H. (2011). A new small molecule specifically inhibits the cariogenic bacterium Streptococcus mutans in multispecies biofilms. Antimicrob. Agents. Chemother. 55, 2679-2687. doi: 10.1128/AAC.01496-10

Martins, M. L., Leite, K. L. F., Pacheco-Filho, E. F., Pereira, A. F. M., Romanos, M. T. V., Maia, L. C., et al. (2018). Efficacy of red propolis hydro-alcoholic extract in controlling Streptococcus mutans biofilm build-up and dental enamel demineralization. Arch. Oral Biol. 93, 56-65. doi: 10.1016/j.archoralbio.2018. 05.017

Matsumoto-Nakano, M., Nagayama, K., Kitagori, H., Fujita, K., Inagaki, S., Takashima, Y., et al. (2011). Inhibitory Effects of Oenothera biennis (Evening Primrose) seed extract on Streptococcus mutans and S. mutans-induced dental caries in rats. Caries Res. 45, 56-63. doi: 10.1159/000323376 
Nyenje, M. E., Green, E., and Ndip, R. N. (2012). Biofilm formation and adherence characteristics of Listeria ivanovii strains isolated from ready-to-eat foods in alice, South Africa. Sci. World J. 2012:873909. doi: 10.1100/2012/873909

Nyvad, B., Crielaard, W., Mira, A., Takahashi, N., and Beighton, D. (2013). Dental caries from a molecular microbiological perspective. Caries Res. 47, 89-102. doi: 10.1159/000345367

Ong, K. S., Mawang, C. I., Daniel-Jambun, D., Lim, Y. Y., and Lee, S. M. (2018). Current anti-biofilm strategies and potential of antioxidants in biofilm control. Expert Rev. Anti. Infect. Ther. 16, 855-864. doi: 10.1080/14787210.2018. 1535898

Pandit, S., Chang, K. W., and Jeon, J. G. (2013). Effects of Withania somnifera on the growth and virulence properties of Streptococcus mutans and Streptococcus sobrinus at sub-MIC levels. Anaerobe 19, 1-8. doi: 10.1016/j.anaerobe.2012. 10.007

Pereira, C. A., Costa, A. C., Carreira, C. M., Junqueira, J. C., and Jorge, A. O. (2013). Photodynamic inactivation of Streptococcus mutans and Streptococcus sanguinis biofilms in vitro. Lasers Med. Sci. 28, 859-864. doi: 10.1007/s10103-0121175-3

Polaquini, C. R., Torrezan, G. S., Santos, V. R., Nazaré, A. C., Campos, D. L., Almeida, L. A., et al. (2017). Antibacterial and antitubercular activities of cinnamylideneacetophenones. Molecules 22:E1685. doi: 10.3390/ molecules22101685

Ren, Z., Chen, L., Li, J., and Li, Y. (2016). Inhibition of Streptococcus mutans polysaccharide synthesis by molecules targeting glycosyltransferase activity. $J$. Oral. Microbiol. 8:31095. doi: 10.3402/jom.v8.31095

Ribeiro, M., Malheiro, J., Grenho, L., Fernandes, M. H., and Simões, M. (2018). Cytotoxicity and antimicrobial action of selected phytochemicals against planktonic and sessile Streptococcus mutans. PeerJ 6:e4872. doi: 10.7717/peerj. 4872

Rosenberg, M. (2006). Microbial adhesion to hydrocarbons: twenty-five years of doing MATH. FEMS Microbiol. Lett. 262, 129-134. doi: 10.1111/j.1574-6968. 2006.00291.x

Senadheera, D., and Cvitkovitch, D. G. (2008). Quorum sensing and biofilm formation by Streptococcus mutans. Adv. Exp. Med. Biol. 631, 178-188. doi: 10.1007/978-0-387-78885-2_12

Senadheera, M. D., Guggenheim, B., Spatafora, G. A., Huang, Y. C., Choi, J., Hung, D. C., et al. (2005). A VicRK signal transduction system in Streptococcus mutans affects gtfBCD, gbpB, and $\mathrm{ftf}$ expression, biofilm formation, and genetic competence development. J. Bacteriol. 187, 4064-4076. doi: 10.1128/jb.187.12. 4064-4076.2005

Svensäter, G., Larsson, U. B., Greif, E. C., Cvitkovitch, D. G., and Hamilton, I. R. (1997). Acid tolerance response and survival byoral bacteria. Oral Microbiol. Immun. 12, 266-273. doi: 10.1111/j.1399-302x.1997.tb00390.x

Tam, K., Kinsinger, N., Ayala, P., Qi, F., Shi, W., and Myung, N. V. (2007). RealTime monitoring of Streptococcus mutans biofilm formation using a quartz crystal microbalance. Caries Res. 41, 474-483. doi: 10.1159/000108321

Topa, S. H., Subramoni, S., Palombo, E. A., Kingshott, P., Rice, S. A., and Blackall, L. L. (2018). Cinnamaldehyde disrupts biofilm formation and swarming motility of Pseudomonas aeruginosa. Microbiology 164, 1087-1097. doi: 10. 1099/mic.0.000692

Veloz, J. J., Saavedra, N., Alvear, M., Zambrano, T., Barrientos, L., and Salazar, L. A. (2016). Polyphenol-rich extract from propolis reduces the expression and activity of Streptococcus mutans glucosyltransferases at subinhibitory concentrations. Biomed. Res. Int. 2016:e4302706. doi: 10.1155/2016/4302706

Viszwapriya, D., Subramenium, G. A., Radhika, S., and Pandian, S. K. (2017). Betulin inhibits cariogenic properties of Streptococcus mutans by targeting vicRK and gtf genes. Antonie Van Leeuwenhoek 110, 153-165. doi: 10.1007/ s10482-016-0785-3

Wu, C., Ayala, E. A., Downey, J. S., Merritt, J., Goodman, S. D., and Qi, F. (2010). Regulation of ciaXRH operon expression and identification of the CiaR regulon in Streptococcus mutans. J. Bacteriol. 192, 4669-4679. doi: 10.1128/JB.00556-10

Xu, X., Zhou, X. D., and Wu, C. D. (2012). Tea catechin epigallocatechin gallate inhibits Streptococcus mutans biofilm formation by suppressing $g t f$ genes. Arch. Oral Biol. 57, 678-683. doi: 10.1016/j.archoralbio.2011.10.021

Yamashita, Y., Bowen, W. H., Burne, R. A., and Kuramitsu, H. K. (1993). Role of the Streptococcus mutans gtf genes in caries induction in the specific-pathogen-free rat model. Infect. Immun. 61, 3811-3817.

Ye, W. H., Fan, B., Purcell, W., Meghil, M. M., Cutler, C. W., Bergeron, B. E., et al. (2019). Anti-biofilm efficacy of root canal irrigants against in-situ Enterococcus faecalis biofilms in root canals, isthmuses and dentinal tubules. J. Dent. 79, 68-76. doi: 10.1016/j.jdent.2018.10.002

Yoshida, Y., Konno, H., Nagano, K., Abiko, Y., Nakamura, Y., Tanaka, Y., et al. (2014). The influence of a glucosyltransferase, encoded by gtfP, on biofilm formation by Streptococcus sanguinis in a dual-species model. APMIS 122, 951-960. doi: 10.1111/apm.12238

Yue, J., Yang, H., Liu, S., Song, F., Guo, J., and Huang, C. (2018). Influence of naringenin on the biofilm formation of Streptococcus mutans. J. Dent. 76, 24-31. doi: 10.1016/j.jdent.2018.04.013

Zhang, H., Zhou, W., Zhang, W., Yang, A., Liu, Y., Jiang, Y., et al. (2014). Inhibitory effects of citral, cinnamaldehyde, and tea polyphenols on mixed biofilm formation by foodborne Staphylococcus aureus and Salmonella Enteritidis. J. Food Prot. 77, 927-933. doi: 10.4315/0362-028X.JFP-13-497

Zhang, J., Liu, J., Ling, J., Tong, Z., Fu, Y., and Liang, M. (2016). Inactivation of glutamate racemase (MurI) eliminates virulence in Streptococcus mutans. Microbiol. Res. 18, 1-8. doi: 10.1016/j.micres.2016.02.003

Conflict of Interest: The authors declare that the research was conducted in the absence of any commercial or financial relationships that could be construed as a potential conflict of interest.

Copyright (c) 2019 He, Huang, Jiang and Zhou. This is an open-access article distributed under the terms of the Creative Commons Attribution License (CC BY). The use, distribution or reproduction in other forums is permitted, provided the original author(s) and the copyright owner(s) are credited and that the original publication in this journal is cited, in accordance with accepted academic practice. No use, distribution or reproduction is permitted which does not comply with these terms. 